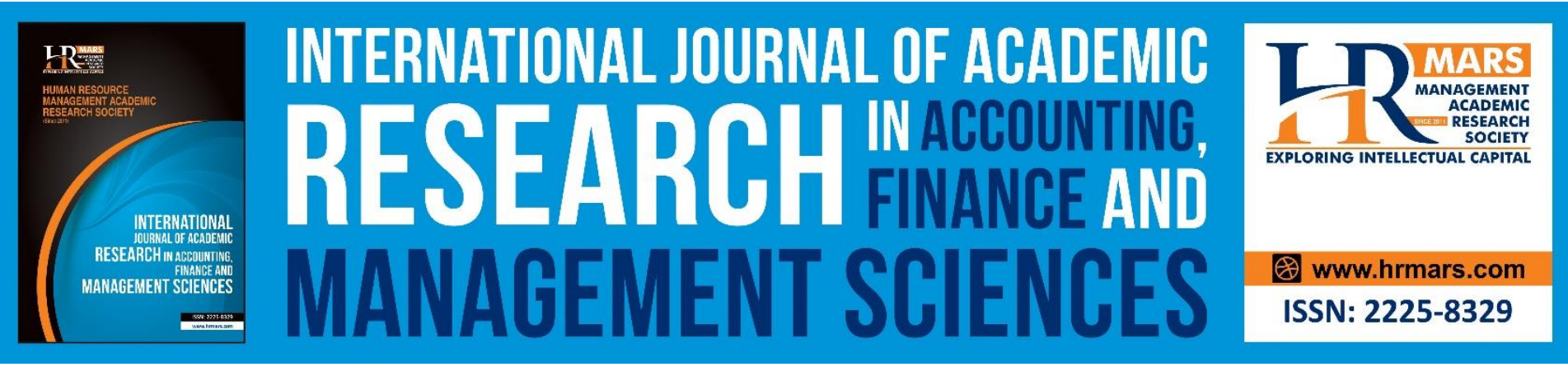

\title{
The Moderating Impact of Local Communities' Attitudes on Tourism Attributes towards Destination Competitiveness of Cat Museum in Kuching
}

Jason, Lim, May Chiun, Lo, Abang Azlan, Mohamad, Wan Hashim Wan, Ibrahim

To Link this Article: http://dx.doi.org/10.6007/IJARAFMS/v10-i3/8002

DOI:10.6007/IJARAFMS /v10-i3/8002

Received: 10 July 2020, Revised: 26 July 2020, Accepted: 28 August 2020

Published Online: 30 September 2020

In-Text Citation: (Lim, Lo, Mohamad, \& Ibrahim, 2020)

To Cite this Article: Lim, J., Lo, M. C., Mohamad, A. A., \& Ibrahim, W. H. W. (2020). The Moderating Impact of Local Communities' Attitudes on Tourism Attributes towards Destination Competitiveness OF Cat Museum in Kuching. International Journal of Academic Research in Accounting, Finance and Management Sciences. 10(3), 418-437.

Copyright: @ 2020 The Author(s)

Published by Human Resource Management Academic Research Society (www.hrmars.com)

This article is published under the Creative Commons Attribution (CC BY 4.0) license. Anyone may reproduce, distribute, translate and create derivative works of this article (for both commercial and non-commercial purposes), subject to full attribution to the original publication and authors. The full terms of this license may be seen at: http://creativecommons.org/licences/by/4.0/legalcode

Vol. 10, No. 3, 2020, Pg. 418 - 437

http://hrmars.com/index.php/pages/detail/IJARAFMS

JOURNAL HOMEPAGE

Full Terms \& Conditions of access and use can be found at http://hrmars.com/index.php/pages/detail/publication-ethics 


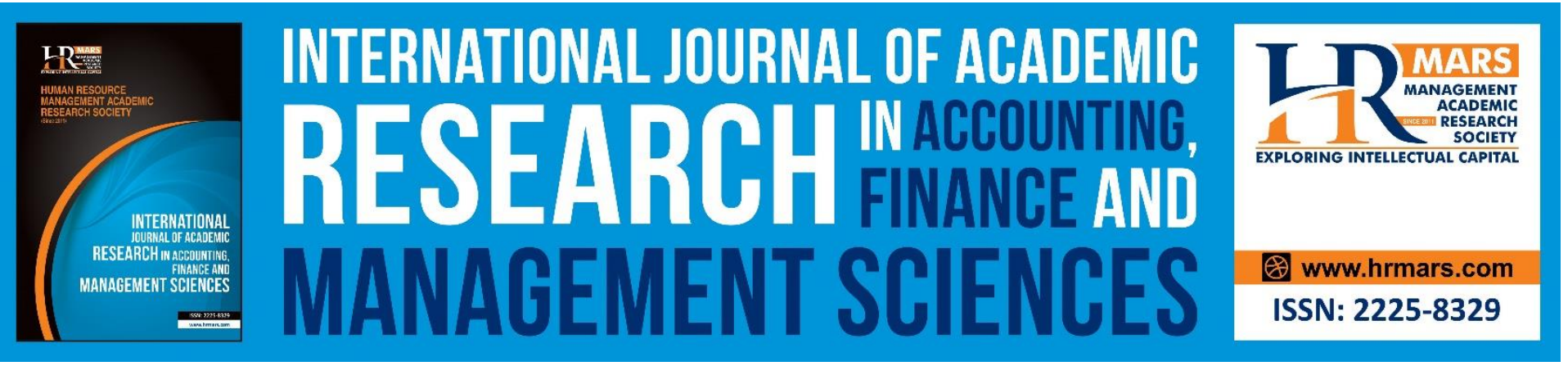

\title{
The Moderating Impact of Local Communities' Attitudes on Tourism Attributes towards Destination Competitiveness of Cat Museum in Kuching
}

\author{
Jason, Lim, May Chiun, Lo, Abang Azlan, Mohamad \\ Faculty of Economics and Business, Universiti Malaysia Sarawak, 94300 Kota Samarahan, Sarawak, \\ Malaysia. \\ Email:limweijason@gmail.com,mclo@unimas.my,maazlan@unimas.my
}

\section{Wan Hashim Wan, Ibrahim}

Chancellery, Universiti Malaysia Sarawak, 94300 Kota Samarahan, Sarawak, Malaysia.

Email: wiwhashim@unimas.my

\begin{abstract}
Tourism attributes such as destination image, tourists' satisfaction and tourists' perceived values are nothing new in the research study on destination competitiveness. These are considered as factors that affect the competitiveness of a destination, however local communities' attitudes (LCA) have yet to be tested whether it has an influence on the relationships on all these three attributes against competitiveness. Hence, Cat Museum in Kuching has been selected as a research site to be tested on, as this site carries its own unique selling proposition and believed to be able to satisfy tourists and given an utmost distinguished value in their travel. This study has introduced the local communities' attitudes into the framework as moderator to test out whether local communities have an influence on these attributes that eventually affect destination competitiveness. For this study, 150 sets of questionnaires in total were collected. Both Statistical Package for Social Science (SPSS) version 23.0 and Smart PLS (version 3.2.7) were used for analyzing the data collected. The findings revealed that destination image, tourists' satisfaction and tourists' perceived values were significantly impacting on destination competitiveness and were proven as positively affecting the destination competitiveness. The implications of the study were further discussed.
\end{abstract}

Keywords: Destination Image, Tourists' Satisfaction, Tourists' Perceived Values, Destination Competitiveness, Cat Museum

\section{Introduction}

A growing trend of travel can be seen throughout the world economy and due to the great value of tourism to the economies, there is a need to focus on tourism sector as it generates lucrative revenues for the economy. As supported by Tang and Tang (2015) and Tugcu (2014), many authors 
INTERNATIONAL JOURNAL OF ACADEMIC RESEARCH IN ACCOUNTING, FINANCE AND MANAGEMENT SCIENCES

Vol. 10, No. 3, 2020, E-ISSN: 2225-8329 ๔ 2020 HRMARS

quoted that the existence of a causal relationship between tourism development and economic expansion. This has portrayed that income has greatly affected by the development. Malaysia's economy was boosted with a total of RM84.1 billion in tourist receipts from the expenditure of 25, 832,354 international tourists who visited Malaysia throughout 2018 (Malaysia Tourism Promotion Board, 2019). The statistics has shown that growth rate of tourism has significantly impact to the economy, this situation has been mentioned by Adinegara (2018) and Haarhoff and De Klerk (2019). Many countries, like Malaysia are giving great attention towards tourism industry too. Simultaneously, the research in the field of tourism specifically destination image, tourists' perception on values, and tourists' satisfaction are getting relatively more important. There are many factors which can make a destination performing and successful. In overall world markets, the competitiveness of a destination as compared to other alternative destinations makes a tourism destination successful (Dwyer, Forsyth, \& Rao, 2000) and as such, the main task of destination management is to focus on enhancing and maintaining the destination competitiveness. Thongma, Leelapattana, and Hung (2012) proposed that the participation of local communities are imperative towards tourism development as communities are instrumental in ensuring that the success of tourism destination sites. Moreover, local communities are vital as they have the ability to impress on visitors with regards to attractions at the destination sites. Therefore, local communities' involvement and support are important in stimulating tourism sites to ensure their success in the long run.

In order to understand, comprehend and further study on destination competitiveness, few attributes have been selected to study on the destination competitiveness of Cat Museum in Kuching, Sarawak. The three identified attributes are Destination Image, Tourists' Satisfaction and Perceived Values. Destination Image is an important factor in tourism destination success (Bigné, Sánchez \& Sánchez, 2001; Court and Lupton, 1997). Esch et al. (2006) and Ha (2004) have quoted that visitors' satisfaction and trust will have an impact on destination. McDougall and Levesque (2000) indicated that perceived values are crucial in determining the success of tourist destination. Twinning-Ward and Butler (2002) also mentioned that supportive attitude of local community is essential and it does contribute for a good experience by tourists. As such, local community perception is important to the success of tourist destination (Cottrell \& Vaske, 2006), failing which the destination will not be able to achieve its objectives and goals. Therefore, the aim of this study is to test the impact of local communities' attitudes involvement as a moderator to tourism attributes (destination image, tourists' satisfaction \& tourists' perceived values) towards destination competitiveness of a selected site - Cat Museum in Kuching. It is regarded as the world's first museum on cats and is devoted to all things connected to the feline. Visitors to Cat Musuem will be able to explore exhibits, photos, art and souvenirs related to cats.

\section{Literature Review}

\section{Destination Competitiveness}

With reference to findings from Novais et al. (2018), the three distinct concepts of destination competitiveness are hierarchically related, it reveals that destination competitiveness as perceptions of a destination, it is as performance and it is a long-term process. In the view of macro perspective in tourism context, competitiveness is the key and also the ultimate goal to improving community's real income in the national concern (Dwyer \& Kim, 2003). As such, destination competitiveness is a broad construct to encompass all environmental, social, cultural and economic variables that leads 
INTERNATIONAL JOURNAL OF ACADEMIC RESEARCH IN ACCOUNTING, FINANCE AND MANAGEMENT SCIENCES

Vol. 10, No. 3, 2020, E-ISSN: 2225-8329 @ 2020 HRMARS

to the performance of the nation in international markets in tourism industry. In order to achieve destination competitiveness, a destination should outshine itself to be different than its rivals, capable of being able to attract new tourists, better off if it could maintain and cultivate loyalty within tourists whom have ever visited the destination earlier (Campo-Martı'nez, Garau-Vadell, Martı'nezRuiz, 2010, Alegre \& Cladera, 2006; Reichheld, 1996). Further emphasized by Li et al. (2013), mentioned that a destination is only considered competitive only when it has ability to convert the advantageous positions of some indicators into tourism revenues. According to Resource-based view theory, it focuses on inimitable 'resources', emphasizing on capabilities and competencies that combining the resources possessed in order to create that sustainable competitive advantage (Barney, 1991; Grant, 1991; Prahalad \& Hamel, 1990). This is the definition by Croes, Ridderstaat, \& Shapoval (2020) in defining sustained competitive advantage in executing value creating strategy that could not be duplicated by current of potential competitors. In other words, the so-called competitive advantage is indeed the core competence. On the micro perspective, in order to stay competitive, the services and fees charged against tourists or offered to tourists must be fair and willingly be paid. Only then, it is attractive to tourists and could stay in business to stand competitive (Dwyer \& Kim, 2003). With matching of theories (e.g., Crouch, 2011; Dwyer, Mellor, Livaic, Edwards, \& Kim, 2004)), Countries with valuable core resources and well-known tourists attraction are more prone to be benefitted from the inflow of tourists in long term (Jalilvand \& Samiei, 2012; Oye, Okafor, \& Kinjir, 2013; Zehrer, Smeral, \& Hallmann, 2016; Yozcu, 2017).

\section{Destination Image, Tourists' Satisfaction and Tourists' Perceived Values}

Destination image defined by Crompton (1979) as "the sum of beliefs, ideas, and impressions that a tourist holds about a destination", some researchers defined it as "a tourist's general impression of a destination" (Coshall, 2000; Fakeye \& Crompton, 1991). Particularly from Fakeye and Crompton (1991), they defined it as an individual's mental representation of knowledge, feelings and general overall perception on a specific destination. It can be constructed as a set of impressions perceived by a tourist about a particular place (Coshall, 2000; Gallarza, Gil, \& Caldero' n, 2002). DI also plays an important role in creating tourist loyalty, and relationships with tourists must be handled proactively if they are to become lasting ones (Bigné, Sánchez and Sánchez, 2001) and as an important factor to affect tourists as close as branding strategy in marketing the destination (Crompton and Ankomah, 1993; Gartner, 1989; Goodall, 1988). Chiu et al. (2016) has conducted an examination on the influence of a destination's image and tourist satisfaction on loyalty among Chinese tourists in Korea. DI is found to go hand-in-hand with satisfaction on loyalty. In the same year there is this study conducted by $\mathrm{Wu}$ (2016) tested a theoretical model of destination image, consumer travel experience, satisfaction and destination loyalty in the tourism context. The study concluded that satisfaction is more inclined to build destination loyalty.

DI is posited by Court and Lupton (1997) to be an essential factor in tourism as it is said to be very influential towards tourists' behavioral intention, it means that if a destination left a positively good image to tourists, then it earns an impact and brighter chance on tourists to return to the same destination again. DI tends to build a relationship with competitive advantage if it happens to be a positive one. With regards to the relations, destination image is obvious that there is inter-relation with satisfaction too. Lee and Lee (2005) have quoted that DI positively influencing perceived quality and satisfaction. A more favourable image will ultimately lead to greater satisfaction and higher values perceived. Scholars Echtner \& Ritchie, 2003 quoted that the chain relations between DI and 
INTERNATIONAL JOURNAL OF ACADEMIC RESEARCH IN ACCOUNTING, FINANCE AND MANAGEMENT SCIENCES

Vol. 10, No. 3, 2020, E-ISSN: 2225-8329 ๑ 2020 HRMARS

satisfaction, DI relates to perceived quality (values); end up perceived quality will reflect the degree of satisfaction (Yan, Wang, \& Chau, 2015). In short, DI not only direct affecting satisfaction but also it has direct relations to tourist' perceived quality (values).

Satisfaction is defined by Rust and Oliver (1994) as the level of positive feelings from the experience; shall the feelings is negative, then it portrays the contrast reaction, which is dissatisfaction. This situation is backed by Reisinger and Turner (2003) saying that a dissatisfied feeling emerged if the experience is displeasure. By having said that, the relationships between perceptions and expectations, is a concept of tourists' satisfaction (Churchill \& Surprenant, 1982). This seems to simplify the whole context in an understandable way. Chen and Phou (2013) quoted that satisfaction or dissatisfaction, is indeed a form of tourists' emotional reaction towards their needs and expectations when travelling to a destination. Tourists' satisfaction is said to be positively affected by DI (Bigné et al., 2001), with prior to visit expectations perceived by tourists when they evaluate depending on their knowledge of place against their post visit experience. The image can positively affect satisfaction and trust and with that it can positively affect visitors' satisfaction and trust toward a destination (Esch et al., 2006; Ha, 2004). Besides, another point has been mentioned, which is the expectation. Jeong et al. (2019) has investigated the relationships between even quality, tourist satisfaction, place attachment and behavioural intentions and concluded that a perception is directly related to satisfaction. This finding depicts the relationship of perception and expectation against satisfaction. In tourism, tourists' satisfaction is a critical factor that impacts destination competitiveness. The causal-effect as explained by Alexandris, Kouthouris and Meligdis (2006), Oppermann, (2000), Bramwell (1998) and Pritchard and Howard (1997) as satisfaction eventually leads to destination loyalty; and destination loyalty reflected by the revisit intentions. Revisit intention will be the ultimate goal that destination competitiveness intends to achieve, with that RI it eases a lot of efforts on promotion, publicity and creating awareness, since recommendations through words of mouth is utmost effective (Oppermann, 2000). This post-purchase behaviour of RI explanation is explained and supported by Hallowell (1996); Rust and Zahorik, (1993) quoting that there is a relation between satisfaction and post-purchase behaviour, and as a sign of loyalty (Cronin et al., 2000; Taylor and Baker, 1994) and a sign of RI (Yoon and Uysal, 2005; Kozak, 2001; Kozak and Rimmington, 2000). In general, in order to be sustainable, experiences formed through the interactions with environments result in value perceptions and satisfaction is said to me important. (Byun \& Jang, 2018; Hwang \& Lee, 2017; Lyu \& Hwang, 2017; Chua, Lee, Goh, \& Han, 2015; Jin, Lee, \& Lee, 2015) This can concluded from Wu, Li, \& Li (2016) and Deng and Pierskalla (2011)'s studies that when tourists' experience quality is satisfactory, then it will lead to the positive experience of perceived value with what they have paid. They are also studies confirming on positive effect of perceived value on satisfaction (Wu et al., 2016; Gallarza et al., 2013; Chen \& Chen, 2010) and so as perceived price on satisfaction (Kim \& Park, 2017; Ali et al., 2016; Han \& Hyun, 2015).

Perceived value has increasingly received attention by researchers but still there is no widely accepted definition exists, the definitions varies. (McDougall and Levesque, 2000; Zenithal, 1988; Woodruff, 1997). As argued, PV is operationalized with single-item scale - "value for money" and this does not address the overall concept of perceived value (Gallarza and Saura, 2006; Sweeney, Soutar, and Johnson, 1999). This argument based on social judgment theory, where Bolton and Drew (1991) posited that when value is the core between cognitive elements of perceived quality or performance, perceived monetary sacrifice and behavioural intentions, then perceived value would be richer measure of consumers' overall evaluation on service than perceived service quality. According to 
INTERNATIONAL JOURNAL OF ACADEMIC RESEARCH IN ACCOUNTING, FINANCE AND MANAGEMENT SCIENCES

Vol. 10, No. 3, 2020, E-ISSN: 2225-8329 @ 2020 HRMARS

Zenithal (1988), perceived value is defined as 'consumer's overall assessment of the utility of a product (or service) based on perceptions of what is received and what is given'. Whereas to Woodruff (1997) it is defined as conceptualized as utility, perceived benefits, price, worth and quality. With evolution of conceptualization, Cravens et al. (1988) suggested that traditionally it is a consumer's value perception treated with ration amount or even as trade-off between quality and price. Somehow, this seems to be the old school of thought. In this study, adoption of definition will be benchmarking on Zenithal's definition.

Kozak and Rimmington (2000), have quoted that perceived values on the quality of travel will determine the satisfaction of consumers. This is again another relationship between the two factors of perceived values and satisfaction because satisfaction in the context of consumption is the outcome of customers' assessment towards the perceived quality or values that they are expecting. Kim and Park (2017) has explored the relationships between perceived value, satisfaction and loyalty in the context of community-based ecotourism in South Korea and found that perceived value significantly predicts satisfaction. On the other hand, Hapsari, Clemes, and Dean (2016) revealed that perceived value is indeed a significant mediator between service quality and satisfaction in the context of aviation industry. As in hospitality sector, guests' perceptions of price have a mediating effect between performance and satisfaction (Ali et al., 2016)

In short, shall the perceived values be met, it will lead to satisfaction; as a result, a destination is said to have destination competitiveness over its rivals. García-Fernández et al. (2018) has conducted an examination on the relationships between perceived quality, service convenience, perceived value, satisfaction, and future intentions, maintaining that perceived quality and service convenience play a pivot role in predicting perceived value. In recent years, the linkage between perceieved quality, perceived value and satisfaction in tourism context has been supported by several studies; hence, the relationships existed (Su et al., 2016; Chen and Chen 2010; De Rojas and Camarero 2008; Severt et al. 2007)

\section{Local Communities' Attitudes}

The tourism industry is regarded as the primary industry that generates revenue for the local community (Lo, Mohamad, Songan \& Yeo, 2012b) and this local community being the beneficiaries tend to react to the tourism activities as a response reflected by tourism. This is what it meant to be as posited by Alam and Paramati (2016) that a highly sustainable tourism model is the one that can net benefits to the poor and increase the employment opportunities for the most vulnerable group in society. Residents of the community started to involve and participate themselves when tourism is blending in. This involvement is known as community involvement and it is defined as the intensity in which residents engage in everyday activities in their residential communities (Lee, 2013) in the context of tourism. Law et al. (2016) mentioned that a successful implementation of sustainable tourism model in developing countries very much depends on committed public and private leadership from various levels; ranging from national level, provincial or state to local levels like the community. With that community involvement, it will then develop and gradually lead to community support as long term gesture which will eventually impact sustainable tourism development.

Community support is essential in achieving STD (Zhang \& Lei, 2012; Choi \& Sirakaya, 2005; Gursoy et al., 2002; Andereck \& Vogt, 2000) and the co-operation from the local community also factoring commercial, social, cultural, physical, political, and economic stability of the industry (Jamaludin, Othman \& Awang, 2009). Hence, community support is working tightly on tourism, as 
INTERNATIONAL JOURNAL OF ACADEMIC RESEARCH IN ACCOUNTING, FINANCE AND MANAGEMENT SCIENCES

Vol. 10, No. 3, 2020, E-ISSN: 2225-8329 @ 2020 HRMARS

quoted by researchers, without the support of local community, it is not possible to sustain tourism (Ahn, Lee \& Shafer 2002; McCool, Moisey \& Nickerson 2001).

As suggested by the social exchange theory, residents tend to support tourism development, when they foresee that expected benefits will exceed costs (Andereck et al., 2005; Gursoy et al., 2002; McGehee \& Andereck, 2004, Fredline \& Faulkner, 2000).Choi (2003) has posited to emphasise the "sense of community" and this is how it actually influences tourism impacts. Sense of community is defined by McMillan (1996) as "spirit of belonging together, a feeling that there is an authority structure that can be trusted, and an awareness that trade and mutual benefit arises by being together, and a spirit that comes from shared experiences that are preserved as art". This could be further explained by Schweitzer (1996) that residents whom uphold a strong sense of community shows more feelings of safety and security, aggressively involved and having greater chance to vote, volunteer and support tourism activities because active welcoming behaviours towards visitors has shown how dedicated a community support. As a result, local community is said to be more sensitive and caring with positive perception of impacts of tourism. This could conclude that attitudes towards tourism is highly affected by the attitudes of the local community. On the other hand, as quoted by Kitnuntaviwat and Tang (2008), that hospitality represents social capital that associated with a destination, it plays an important role in tourism initiatives. Therefore, destinations that succeeded to provide genuine hospitality are at an advantage over those that do not. Hospitality comes from local community support with positive attitudes towards tourism. According to Eshliki and Kaboudi (2012) the attitude of local community is valuable for decision makers and local communities' benefit from tourism from an economic perspective. It is obvious that sustainable tourism requires local communities support, if locals were poorly informed, marginalized and alienated from decision making then likelihood that they become inhospitable attitudes toward current and future development in tourism is unescapable (Butcher, 1997). The focus from the researchers now are eyeing on the impact of tourism on the local communities. This has become a major topic for researchers while being the key element in building sustainable and long-term tourism strategies (Almeida et al., 2016; Dutescu et al., 2012). This has made local community has become one of the most important stakeholders of the tourism industry (Lo et al. 2014, Cañizares et al. 2014). It is sound to make another reference to Sinclair-Maragh et al. (2017), Rasoolimanesh et al. (2017), Kyle et al. (2017) and Nunkoo et al. (2015) on their statement on local's support has become a critical issue for researchers.

\section{Hypotheses Development \\ Destination Image, Tourists' Satisfaction and Tourists' Perceived Values Factoring Destination Competitiveness}

In the context of destination competitiveness, many studies are done which shows different aspects. For analyzing strengths and weakness of a destination, identification of the destination image is necessary (Chen and Uysal, 2002). Due to its importance, destination image has received a lot of attention in tourism research (Gartner and Hunt, 1987; Oppermann, 1996). To assure competitive success, the image of the destination in tourist mind is crucial. (Telisman-Kosuta, 1994).

Tourists' satisfaction is referred to the tourist expectation before and after tour about a destination. If experiences are good as compared to expectations, it results in satisfaction. If experience is bad, then the tourist will be dissatisfied (Reisinger and Turner, 2003). Many past studies 
INTERNATIONAL JOURNAL OF ACADEMIC RESEARCH IN ACCOUNTING, FINANCE AND

MANAGEMENT SCIENCES

Vol. 10, No. 3, 2020, E-ISSN: 2225-8329 @ 2020 HRMARS

have examined satisfaction has in tours, destinations and accommodation (Lee, Lee \& Lee, 2005; Yoon \& Uysal, 2005)

Perceived value is conceptualized differently by different authors (McDougall \& Levesque, 2000). According to Zeithaml (1988), 'the evaluation of the usefulness of a commodity from the perception of what is received and what is given is the perceived value'. Cravens et al. (1988) defined the perceived value based on the aspect of price and quality. In the tourism context, the perceived value is defined as the difference between the advantage and the price of the offerings of destination (Bajs, 2015).

The relations between the destination image, tourists' satisfaction and tourists' perceived values to the destination competitiveness is reciprocal, the more positively these constructs impacted, the more competitive the destination to be and vice versa. Hence, the proposed hypotheses are:

$\mathrm{H} 1$ : Destination image is positively related the destination competitiveness.

$\mathrm{H} 2$ : Tourists' satisfaction is positively related the destination competitiveness.

H3 : Tourists' perceived values are positively related the destination competitiveness.

\section{Local Community Attitudes Moderate Tourism Attributes on Destination Competitiveness}

The framework of this paper is having local communities' attitudes to moderate the factors that influence destination competitiveness, hence hypothesis $\mathrm{H} 4, \mathrm{H} 5$ and $\mathrm{H} 6$ are constructed. There is a strong linkage between community involvement in tourism development (Nzama 2008). Local communities' attitudes have played a very important part in determining the competitiveness. The participation by community is vital for a sustainability of tourism destination (Zhang \& Lei, 2012). Local communities play a role as hosts for tourists, past researchers suggest that maintaining tourism to a destination is not possible if local communities are not supportive (Ahn, Lee \& Shafer 2002; Twinning-Ward \& Butler, 2002; McCool, Moisey \& Nickerson, 2001;). Support from local communities for tourism is essential to ensure the economic and socio-cultural sustainability of the tourism sector. According to Nunkoo \& Ramkissoon, (2011) past studies have suggested that support from local community is also affected by their attitudes. The attitude of local communities evaluates the current situation to the destination to the great extent because of the closeness of the area (Cottrell \& Vaske 2006). The proposed hypotheses are:

H4 : Local communities' attitudes are positively moderating the relationship between destination image and destination competitiveness; such that when local communities' attitudes are high the relationship between destination image and destination competitiveness will be stronger.

H5 : Local communities' attitudes are positively moderating the relationship between tourists' satisfaction and destination competitiveness; such that when local communities' attitudes are high the relationship between tourists' satisfaction and destination competitiveness will be stronger.

H6 : Local communities' attitudes are positively moderating the relationship between tourists' perceived values and destination competitiveness; such 
INTERNATIONAL JOURNAL OF ACADEMIC RESEARCH IN ACCOUNTING, FINANCE AND

MANAGEMENT SCIENCES

Vol. 10, No. 3, 2020, E-ISSN: 2225-8329 ๔ 2020 HRMARS

that when local communities' attitudes are high the relationship between tourists' perceived values and destination competitiveness will be stronger.

\section{Methodology}

Cat Museum has been the selected site for the study. Tourists from foreign countries and within Malaysia (Peninsula) have been approached for the questionnaire survey, in other words they are the targeted respondents. As for the tool used for this research is by using pre-set questionnaire conducted by interviewer to respondents face-to-face with immediate clarifications from interviewer, shall it deem to be necessary. This is a quantitative approach in Confirmatory Factor Analysis manner to measure and assess the study. The structure of the questionnaire is divided into four parts. The first section, collecting the demographic information of the respondents, then followed by the second section which will be multiple questions seeking respondents' feedback on the variables of destination image, tourists' satisfaction, tourists' perceived values and on competitiveness of the destination and with the influence of local communities' attitudes. In between the questions in section two, it slotted-in a section where ranking the priority of respondents on their priority of their visits (prioritize with $1=$ utmost priority to $7=$ least priority). On the multiple questions section, questions are adapted from Artuğer (2015); Herstanti, Suhud and Wibowo (2014); Canny and Hidayat (2012); Chi and Qu (2008); Collins (2005), questions are modified to cater and suit the use in a domestic context. A seven-pointer Likert scale (ranging from $1=$ strongly disagree to $7=$ stronger agree) to the question is used to lead the respondents to the best describe of the degree of agreement.

There are also some restrictions set on selection of respondents approached. Minority aged below 16-year-old would not be eligible to be interviewed, this is to maintain the level of maturity and standard set to the analysis. Purposive and random technique is adopted towards approaching respondents to ensure no favoritism and bias. G* Power software is used to determine the sample size required to justify the explanatory level of the model constructed. By using medium effect size to priori power analysis, the minimum sample size suggested is 150 . A total of 150 sets of questionnaires have been successfully collected, and at the preliminary stage analysis those data were processed by using Statistical Package for Social Science 23.0 (SPSS). This software application is used to address missing values and straight lining. At the following stage, data were then analyzed by PLS-SEM technique with software of Smart PLS (version 3.2.7). There were two stages for running this analysis. At first stage the research model or measurement model (Fig. 1) is run with algorithm followed by bootstrapping with 5,000 resample for generating the standard errors of the estimation and $p$ values.

\section{Findings}

\section{Assessment of the Measurement Model}

Measurement scales reliability, convergent reliability and discriminant validity were all need to be tested under confirmatory factor analysis (CFA) approach. Referred to Bagozzi, Yi and Philips (1991), the loadings of each constructs refrained at Table 1, needed to be maintained at the minimum cut off point of 0.5 and above to meet the internal consistency. According to Chin (2010), composite reliability $(C R)$ values which greater than the minimum cut off point of 0.7 would be refrained and declared as valid. For average variance extracted (AVE) values, it should be greater than minimum 
INTERNATIONAL JOURNAL OF ACADEMIC RESEARCH IN ACCOUNTING, FINANCE AND MANAGEMENT SCIENCES

Vol. 10, No. 3, 2020, E-ISSN: 2225-8329 @ 2020 HRMARS

criteria of 0.50 according to suggestion posited by Fornell and Larcker (1981). It is mandating that CR's and AVE's values have to meet minimum criteria respectively. Besides, to test on the reliability and internal consistency of the instrument, Cronbach's alpha values were also been used for that purpose and indicating that the alpha values are considered at good level (Cronbach, 1951). Referring to Nunally and Bernstein (1994), alpha's values at $0.60,0.61-0.79$, and above 0.80 is considered poor, acceptable and good respectively.

As for the discriminant validity, there are two tables been shown; Table 2, the Fornell and Larcker (1981) criterion, and Table 3, Heterotrait-Monotrait (HTMT) ration. The value of AVE was square rooted and testified against the inter-correlation of the construct with other constructs under the same research model (Chin, 2010). According to Kline (2011), the rule of thumb is that the ratio should not $\mathrm{HTMT}_{0.85}$ value of 0.85 or $\mathrm{HTMT}_{0.90}$ value of 0.90 according to Gold, Malhotra, and Segars (2001). Under the mentioned situation, the measurement model is regarded as reliable and valid, witnessing that it provides sufficient evidences in term of reliability, convergent validity, and discriminant validity. The coefficient of determination $\left(R^{2}\right)$ was 0.697 for destination competitiveness, which indicated more than $69.7 \%$ of the construct. The $R^{2}$ was above the moderate indication as suggested by Cohen (1998) which is slightly above the moderate model of $R 2 \_0.33$.

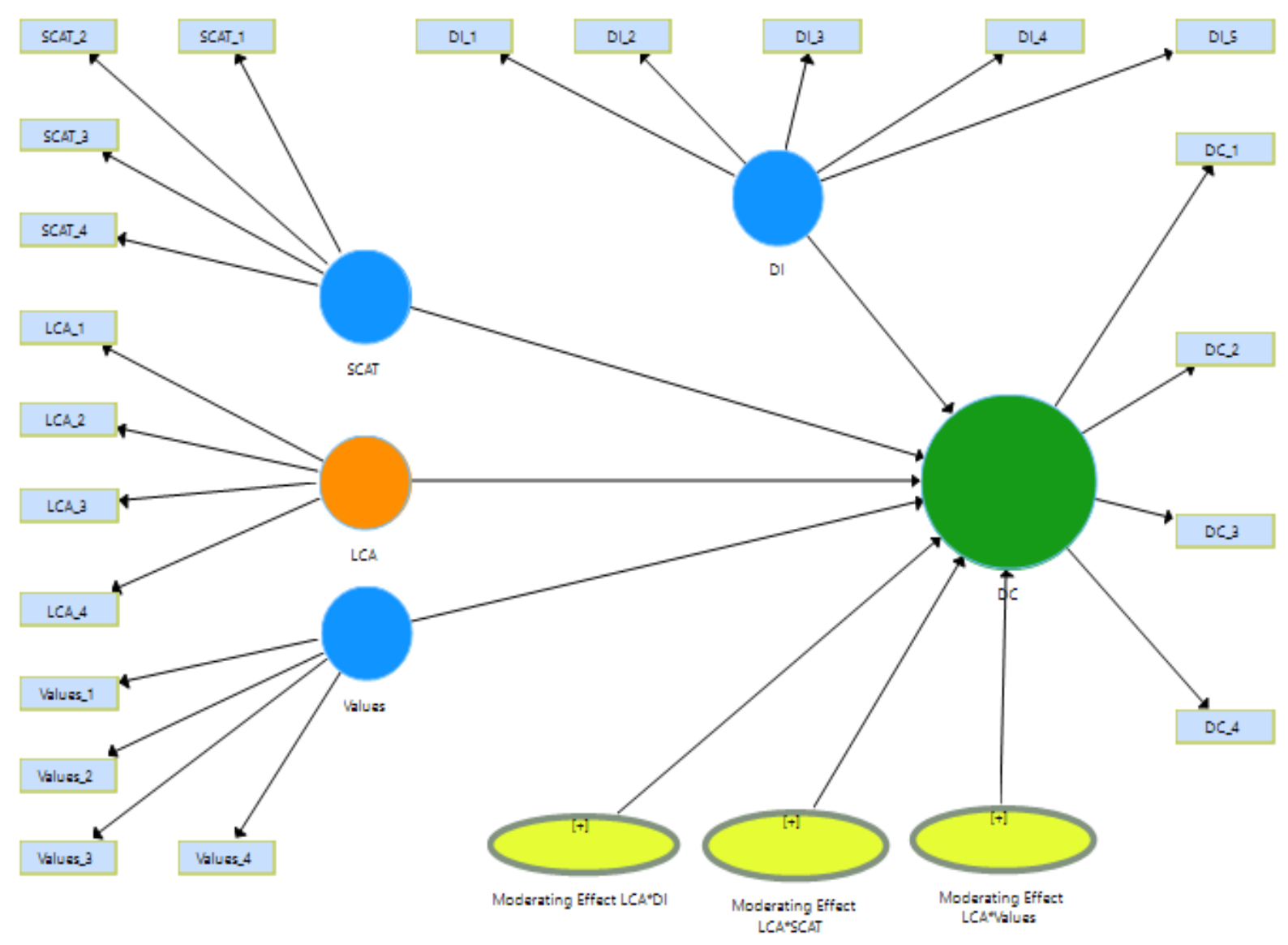

Figure 1: Research model 
INTERNATIONAL JOURNAL OF ACADEMIC RESEARCH IN ACCOUNTING, FINANCE AND MANAGEMENT SCIENCES

Vol. 10, No. 3, 2020, E-ISSN: 2225-8329 @ 2020 HRMARS

Table 1: Results of measurement model

\begin{tabular}{|c|c|c|c|c|c|}
\hline Construct & Items & Loadings & CR & $\begin{array}{c}\text { Cronbach' } \\
\text { s Alpha }\end{array}$ & AVE \\
\hline \multirow{5}{*}{$\begin{array}{l}\text { Destination } \\
\text { Image }\end{array}$} & DI_1 & 0.860 & 0.939 & 0.919 & 0.756 \\
\hline & DI_2 & 0.859 & & & \\
\hline & DI_3 & 0.892 & & & \\
\hline & DI_4 & 0.890 & & & \\
\hline & DI_5 & 0.847 & & & \\
\hline Tourists' & SCAT_1 & 0.943 & 0.961 & 0.945 & 0.859 \\
\hline \multirow[t]{3}{*}{ Satisfaction } & SCAT_2 & 0.930 & & & \\
\hline & SCAT_3 & 0.935 & & & \\
\hline & SCAT_4 & 0.899 & & & \\
\hline Tourists' & Values_1 & 0.882 & 0.935 & 0.907 & 0.782 \\
\hline \multirow[t]{3}{*}{$\begin{array}{l}\text { Perceived } \\
\text { Values }\end{array}$} & Values_2 & 0.878 & & & \\
\hline & Values_3 & 0.922 & & & \\
\hline & Values_4 & 0.854 & & & \\
\hline Local & LCA_1 & 0.905 & 0.937 & 0.910 & 0.787 \\
\hline Communities' & LCA_2 & 0.903 & & & \\
\hline \multirow[t]{2}{*}{ Attitudes } & LCA_3 & 0.882 & & & \\
\hline & LCA_4 & 0.858 & & & \\
\hline Destination & DC_1 & 0.830 & 0.915 & 0.877 & 0.730 \\
\hline Competitivene & DC_2 & 0.875 & & & \\
\hline \multirow[t]{2}{*}{ SS } & DC_3 & 0.885 & & & \\
\hline & DC_4 & 0.826 & & & \\
\hline
\end{tabular}

Note:

a Composite Reliability (CR)

${ }^{\mathrm{b}}$ Average Variance Extracted (AVE)

Table 2: Discriminant validity of constructs (Fornell \& Larcker criterions)

\begin{tabular}{lllllll} 
& & 1 & 2 & 3 & 4 & 5 \\
\hline $\mathbf{1}$ & DC & $\mathbf{0 . 8 5 5}$ & & & & \\
$\mathbf{2}$ & DI & 0.762 & $\mathbf{0 . 8 7 0}$ & & & \\
$\mathbf{3}$ & LCA & 0.630 & 0.541 & $\mathbf{0 . 8 8 7}$ & & \\
$\mathbf{4}$ & SCAT & 0.707 & 0.695 & 0.615 & $\mathbf{0 . 9 2 7}$ & \\
$\mathbf{5}$ & Values & 0.704 & 0.745 & 0.551 & 0.667 & 0.885 \\
\hline
\end{tabular}

Note: Diagonals represent the square root of the average variance extracted (AVE) while the other entries represent the correlations. 
Table 3: Discriminant validity of constructs (HTMT)

\begin{tabular}{ll|rrrrr} 
& & 1 & 2 & 3 & 4 & 5 \\
\hline 1 & DC & & & & & \\
2 & DI & 0.845 & & & & \\
3 & LCA & 0.704 & 0.590 & & & \\
4 & SCAT & 0.777 & 0.745 & 0.662 & & \\
5 & Values & 0.788 & 0.813 & 0.603 & 0.718 & \\
\hline
\end{tabular}

\section{Assessment of the Structural Model}

Table 4 is presenting the results of hypotheses testing, regards that for one-tailed hypotheses testing, the $t$ value should exceed 1.645 or 2.33 . The statistical results indicated that all three of the direct relationship hypotheses tested were found supported.

Destination image, Tourists' satisfaction and tourists' perceived values all have a positive impact on destination competitiveness. Local community attitude which is used as a moderator also showed a positive impact on destination competitiveness. $\mathrm{H} 5$ and $\mathrm{H} 6$ are the hypothesis in which local community attitude use as a moderator between tourists' satisfaction and destination competitiveness and tourists' perceived values with the destination competitiveness respectively was not supported., To check whether there is multicollinearity issue is presented among the independent variables of destination image, tourists' satisfaction and tourists' perceived values, the value of variation inflation factor (VIF) values were obtained. The results indicated that no multicollinearity issue exist among the construct as all the VIF values were below 10, which is confirmed with the rule mentioned by Bock, Zmud, Kim and Lee, 2005. Blindfolding procedures was performed to obtain the $Q^{2}$ value which explain the predictive relevance of the model Hair, Hult, Ringle, and Sarstedt (2016) presented that the $Q^{2}$ value of more than zero value is relevant, thus the $\mathrm{Q}^{2}$ value of destination competitiveness is 0.515 (see Table 5). 
INTERNATIONAL JOURNAL OF ACADEMIC RESEARCH IN ACCOUNTING, FINANCE AND MANAGEMENT SCIENCES

Vol. 10, No. 3, 2020, E-ISSN: 2225-8329 @ 2020 HRMARS

Table 4: Path coefficients and hypothesis testing

\begin{tabular}{|c|c|c|c|c|c|c|c|}
\hline $\begin{array}{l}\text { Hypothes } \\
\text { is }\end{array}$ & Relationship & $\begin{array}{l}\text { Standa } \\
\text { rd Beta }\end{array}$ & $\begin{array}{l}\text { Standa } \\
\text { rd } \\
\text { Error }\end{array}$ & $\begin{array}{c}\text { t- } \\
\text { value }\end{array}$ & Decision & VIF & $f^{2}$ \\
\hline $\mathrm{H} 1$ & $\begin{array}{l}\text { Destination image } \rightarrow \\
\text { destination } \\
\text { competitiveness }\end{array}$ & 0.396 & 0.084 & $\begin{array}{c}4.714 \\
* *\end{array}$ & $\begin{array}{c}\text { Support } \\
\text { ed }\end{array}$ & 2.712 & 0.191 \\
\hline $\mathrm{H} 2$ & $\begin{array}{l}\text { Tourists' satisfaction } \\
\rightarrow \text { destination } \\
\text { competitiveness }\end{array}$ & 0.250 & 0.085 & $\begin{array}{c}2.941 \\
* *\end{array}$ & $\begin{array}{c}\text { Support } \\
\text { ed }\end{array}$ & 2.769 & 0.075 \\
\hline $\mathrm{H} 3$ & $\begin{array}{l}\text { Tourists' perceived } \\
\text { values } \rightarrow \text { destination } \\
\text { competitiveness }\end{array}$ & 0.158 & 0.075 & $\begin{array}{c}2.107 \\
*\end{array}$ & $\begin{array}{c}\text { Support } \\
\text { ed }\end{array}$ & 2.737 & 0.030 \\
\hline $\mathrm{H} 4$ & $\begin{array}{l}\text { Local Communities' } \\
\text { Attitudes moderate } \\
\text { Destination image } \\
\text { and destination } \\
\text { competitiveness }\end{array}$ & 0.140 & 0.084 & $\begin{array}{c}1.667 \\
*\end{array}$ & $\begin{array}{c}\text { Support } \\
\text { ed }\end{array}$ & 2.831 & 0.027 \\
\hline H5 & $\begin{array}{l}\text { Local Communities' } \\
\text { Attitudes moderate } \\
\text { Tourists' satisfaction } \\
\text { and destination } \\
\text { competitiveness }\end{array}$ & 0.019 & 0.073 & 0.260 & $\begin{array}{c}\text { Not } \\
\text { Supporte } \\
\text { d }\end{array}$ & 2.837 & 0.001 \\
\hline H6 & $\begin{array}{l}\text { Local Communities' } \\
\text { Attitudes moderate } \\
\text { Tourists' perceived } \\
\text { values and } \\
\text { destination } \\
\text { competitiveness }\end{array}$ & -0.060 & 0.081 & 0.741 & $\begin{array}{l}\text { Not } \\
\text { Supporte } \\
\text { d }\end{array}$ & 2.953 & 0.005 \\
\hline
\end{tabular}

Note: $p<0.05^{*} ; p<0.01^{* *}$

Table 5: The results of the prediction values

\begin{tabular}{|c|c|c|c|}
\hline & SSO & SSE & $\mathrm{Q}^{2}(=1-\mathrm{SSE} / \mathrm{SSO})$ \\
\hline Destination Competitiveness & 600.000 & 291.054 & 0.515 \\
\hline Destination image & 750.000 & 303.837 & 0.595 \\
\hline Tourists' satisfaction & 600.000 & 187.909 & 0.687 \\
\hline Tourists' perceived values & 600.000 & 248.836 & 0.585 \\
\hline Moderating Effect LCA*DI & $3,000.000$ & $1,913.519$ & 0.362 \\
\hline Moderating Effect LCA*SCAT & $2,400.000$ & $2,129.515$ & 0.113 \\
\hline $\begin{array}{l}\text { Moderating } \quad \text { Effect } \\
\text { LCA*Values }\end{array}$ & $2,400.000$ & $1,662.883$ & 0.307 \\
\hline $\begin{array}{l}\text { Local Communities' Attitudes } \\
\text { (M) }\end{array}$ & 600.000 & 244.899 & 0.592 \\
\hline
\end{tabular}


INTERNATIONAL JOURNAL OF ACADEMIC RESEARCH IN ACCOUNTING, FINANCE AND MANAGEMENT SCIENCES

Vol. 10 , No. 3, 2020, E-ISSN: $2225-8329$ @ 2020 HRMARS

\section{Discussion}

With Reference to $\mathrm{H} 1$, it is confirmed that destination image impact positively on the destination competitiveness. Destination image is the overall perception in the mind of the tourists towards a particular destination (Fakeye \& Crompton,1991), so the better off the image of a particular destination the more competitive advantages the destination gained.

Tourists' satisfaction impact from $\mathrm{H} 2$, it is confirmed that the satisfaction level of the tourists has a positive effect towards destination competitiveness. The competitive advantage of a particular destination over the others has increased, if the satisfaction level of the tourists towards that particular destination is high. The scenario is that satisfied tourists are the source of publicity that promotes the destination which ultimately increased the destination competitiveness. Incorporation of local community attitude and support bounces the tourist industry to expand and grow (Hanafiah, Jamaluddin \& Zulkifly, 2013). In an indirect manner, local community positive attitude has a favorable impact over tourists; it has the potential to influence level of satisfaction of tourists. This satisfaction level will positively lead their intention to re-visit and it also increases their recommendations to other through words of mouth (Gursoy \& Rutherford, 2004).

With reference to $\mathrm{H} 3$, it is also accepted that the tourists' perceived values positively impact on the destination competitiveness. As quoted earlier literature by Kozak and Rimmington (2000) and Fornell, Johnson, Anderson, Cha and Bryant (1996), satisfaction very much affected by the perceived values, so since the destination is highly valued then it will be promoted and good reputation will have a direct impact on its competitiveness. Satisfaction again is related and being influential towards the competitiveness.

\section{Conclusion, Theoretical and Practical Implications}

To conclude, looking at the finding from the results, destination image, tourists' satisfaction and tourists' perceived values are positively impacted and significantly related to the destination competitiveness as $\mathrm{H} 1, \mathrm{H} 2$ and $\mathrm{H} 3$ were all shown supported. The local community attitude seems to be moderating the relationship between destination image and destination competitiveness well, as $\mathrm{H} 4$ was also shown supported. However local community attitude does not seem to be moderating the relationship between tourists' satisfaction towards destination competitiveness and between tourists' perceived values towards destination competitiveness, therefore $\mathrm{H} 5$ and $\mathrm{H} 6$ are not significant. In referring to the findings of this research, locals seem to be very proud of their current surroundings and they are capable of promoting the environmental factor that they possessed. However, they seem to be poor in winning the tourists' satisfactions and does not let the visitors felt worth their efforts in visiting the destination. It is very much worth considering the knowledge on tourism among the local community. Perhaps, visitors are not satisfied or rather not feeling worthy in visiting the destinations is not over solely putting on a blame on the communities' attitudes; but rather it could be because of service rendered by the community. These locals might not be welltrained in term of hospitality and catering. Hence, they do not meet the expectations of the visitors. Otherwise, with the advantage on destination image it is quite impossible to jeopardize the other two variables, which are satisfaction and perceived values. Being another reason on hand, the locals should seriously look into the pricing that they imposed and the variety of exhibits. The possible 
INTERNATIONAL JOURNAL OF ACADEMIC RESEARCH IN ACCOUNTING, FINANCE AND MANAGEMENT SCIENCES

Vol. 10, No. 3, 2020, E-ISSN: 2225-8329 @ 2020 HRMARS

reason that causing low ratings on satisfaction and perceived values could be affected by fees that imposed and also the artefacts that been exhibited. It could be over-priced or over-charged by the local operators that triggered the visitors' unfavoured responses, another possibility is the less attractive artefacts. In the long run, shall these feedbacks not been seriously taken into solution and reasons not been rectified, it could eventually turn into a weakness and serve as an opportunity to overturn the game by other destinations. Indeed, it is very critical and alarming to the stakeholders and the local government authorities. It is recommended to investigate further the research framework in other destination which is similar to Cat Museum to test the outcome. On the other hand, it is worth investigating on this museum itself on the reasons why research triggered unsatisfactory visitors and low values perceived by visitors.

\section{Acknowledgement}

The funding for this project was made possible through the research grant obtained from Sarawak Multimedia Authority and Universiti Malaysia Sarawak [RG/F01/SMA/12/2018].

\section{References}

Ahn, B., Lee, B., \& Shafer, C. S. (2002). Operationalizing sustainability in regional tourism planning: an application of the limits of acceptable change framework. Tourism Management, 23(1), 1-15.

Alexandris, K., Kouthouris, C., \& Meligdis, A. (2006). Increasing customers' loyalty in a skiing resort: The contribution of place attachment and service quality. International Journal of Contemporary Hospitality Management, 18(5), 414-425

Anderson, E. W., \& Sullivan, M. W. (1993). The antecedents and consequences of customer satisfaction for firms. Marketing Science, 12, 125-143.

Baloglu, S., \& McCleary, K. W. (1999). A model of destination image formation. Annals of Tourism Research, 26(4), 868-897.

Beeho, A. J., \& Prentice, R. C. (1997). Conceptualizing the experiences of heritage tourists. Tourism Management, 18(2), 75-87.

Bigne, J. E., Sa'nchez, M. I., \& Sa'nchez, J. (2001). Tourism image, evaluation variables and after purchase behaviour: Inter-relationship. Tourism Management, 22(6), 607-616

Bock, G. W., Zmud, R. W., Kim, Y. G., \& Lee, J. N. (2005). Behavioral intention formation in knowledge sharing: Examining the roles of extrinsic motivators, social-psychological forces, and organizational climate. MIS Quarterly, 29(1), 87-111.

Bramwell, B. (1998). User satisfaction and product development in urban tourism. Tourism Management, 19(1), 35-47.

Castro, C. B., Armario, E. M., \& Ruiz, D. M. (2007). The influence of market heterogeneity on the relationship between a destination's image and tourists' future behavior. Tourism Management, 28, 175-187.

Chen, J. S., \& Uysal, M. (2002). Market positioning analysis: A hybrid approach. Annals of Tourism Research, 29(4), 987-1003.

Chin, W. W. (2010). How to write up and report PLS analyses. In V.Esposito Vinzi, W.W.Chin, J.Henseler, \& H.Wang (Eds.), Handbook of partial least squares: Concepts, methods and application. New York: Springer, 645-689. 
INTERNATIONAL JOURNAL OF ACADEMIC RESEARCH IN ACCOUNTING, FINANCE AND

MANAGEMENT SCIENCES

Vol. 10, No. 3, 2020, E-ISSN: 2225-8329 @ 2020 HRMARS

Chon, K. S. (1990). The role of destination image in tourism: A review and discussion. Tourist Review, 45(2), 2-9.

Churchill, Jr, G. A., \& Surprenant, C. (1982). An investigation into the determinants of customer satisfaction. Journal of Marketing Research, 19(4), 491-504.

Cohen, J. (1998), Statistical Power Analysis for the Behavioural Sciences, 2nd ed., Psychology Press, New York, NY.

Cottrell, S. P., \& Vaske, J. J. (2006). A framework for monitoring and modeling sustainable tourism. E-Review of Tourism Research, 4(4), 74-84.

Court, B., \& Lupton, R. A. (1997). Customer portfolio development: Modeling destination adopters, inactives, and rejecters. Journal of Travel Research, 36(1), 35-43.

Cracolici, M. F., \& Nijkamp, P. (2009). The attractiveness and competitiveness of tourist destinations: A study of Southern Italian regions. Tourism Management, 30(3), 336-344.

Cravens, D. W., Holland, C. W., Lamb Jr, C. W., \& Moncrief III, W. C. (1988). Marketing's role in product and service quality. Industrial Marketing Management, 17(4), 285-304.

Croes, R., Ridderstaat, J., \& Shapoval, V. (2020). Extending tourism competitiveness to human development. Annals of Tourism Research, 80(1), 1-15.

Crompton, J. L. (1979). Motivations for pleasure vacation. Annals of tourism research, 6(4), 408 424.

Crompton, J. L., \& Ankomah, P. K. (1993). Choice set propositions in destination decisions. Annals of Tourism Research, 20(3), 461-476.

Cronbach, L. J. (1951). Coefficient alpha and the internal structure of tests. psychometrika, 16(3), 297-334.

Cronin, J. J. Jr., Brady, M. K., \& Hult, G. T. M. (2000). Assessing the effects of quality, value and customer satisfaction on consumer behavioural intentions in service environments. Journal of Retailing, 76(2), 193-218.

Crouch, G. I. (2007). Modelling Destination Competitiveness: A Survey and Analysis of the Impact of Competitiveness Attributes. Australia: CRC for Sustainable Tourism Pty Ltd

Danaher, P. J., \& Arweiler, N. (1996). Customer satisfaction in the tourist industry: A case study of visitors to New Zealand. Journal of Travel Research, 35(1), 89-93.

Dwyer, L., \& Kim, C. (2003). Destination competitiveness: Determinants and indicators. Current Issues in Tourism, 6(5), 369-414.

Dwyer, L., Forsyth, P., \& Rao, P. (2000). The price competitiveness of travel and tourism: A comparison of 19 destinations. Tourism Management, 21(1), 9-22.

Echtner, C. M., \& Ritchie, J. B. (1991). The meaning and measurement of destination image. Journal of Tourism Studies, 2(2), 2-12.

Echtner, C. M., \& Ritchie, J. R. B. (2003). The meaning and measurement of destination image. The Journal of Tourism Studies, 14(1), 37-48.

Eshliki, S. A., \& Kaboudi, M. (2012). Community perception of tourism impacts and their participation in tourism planning: a case study of Ramsar, Iran. Procedia-Social and Behavioral Sciences, 36, 333-341.

Fakeye, P. C., \& Crompton, J. L. (1991). Image differences between prospective, first-time, and repeat visitors to the Lower Rio Grande Valley. Journal of Travel Research, 30(2), 10-16.

Fornell, C., Johnson, M. D., Anderson, E. W., Cha, J., \& Bryant, B. E. (1996). The American customer satisfaction index: Nature, purpose, and findings. Journal of Marketing, 60(Oct.), 7-18. 
INTERNATIONAL JOURNAL OF ACADEMIC RESEARCH IN ACCOUNTING, FINANCE AND

MANAGEMENT SCIENCES

Vol. 10, No. 3, 2020, E-ISSN: 2225-8329 @ 2020 HRMARS

Fornell, C., \& Larcker, D. F. (1981). Structural equation models with unobservable variables and measurement error: Algebra and statistics.

Gartner, W. C. (1989). Tourism image: Attribute measurement of state tourism products using multidimensional scaling techniques. Journal of Travel Research, 28(2), 16-20.

Gartner, C. G., \& Hunt, J. D. (1987). An analysis of state image change over a twelve-year period (1971-1983). Journal of Travel Research. Fall: 15-19.

Gold, A. H., Malhotra, A., \& Segars, A. H. (2001). Knowledge management: an organizational capabilities perspective. Journal of Management Information Systems, 18(1), 185-214.

Goodrich, J. N. (1977). Benefit bundle analysis: An empirical study of international travelers. Journal of Travel Research, 16(2), 6-9.

Goodall, B. (1988). How tourists choose their holidays: An analytical framework. In B. Goodall, \&G. Ashworth (Eds.), Marketing in the tourism industry: The promotion of destination regions (pp. 1-17). London: Routledge.

Gursoy, D., \& Rutherford, D. G. (2004). Host attitudes toward tourism: An improved structural model. Annals of tourism Research, 31(3), 495-516.

Hair, J. F., Hult, G. T. M., Ringle, C. M., \& Sarstedt, M. (2016). A Primer on Partial Least Squares Structural Equation Modelling (PLS-SEM) (2nd ed.). Thousand Oaks, CA: Sage.

Hallowell, R. (1996). The relationship of customer satisfaction, customer loyalty, profitability: An empirical study. International Journal of Service Industry Management, 7(4), 27-42.

Hanafiah, M. H., Jamaluddin, M. R., \& Zulkifly, M. I. (2013). Local community attitude and support towards tourism development in Tioman Island, Malaysia. Procedia-Social and Behavioral Sciences, 105, 792-800.

Hsu, C. H. (2003). Mature motor-coach travelers' satisfaction: A preliminary step toward measurement development. Journal of Hospitality and Tourism Research, 20(10), 1-19.

Jalilvand, M. R., \& Samiei, N. (2012). The impact of electronic word of mouth on a tourism destination choice. Internet Research, 22(5), 591-612.

Jamaludin, M., Othman, N., \& Awang, A. R. (2012). Community based homestay programme: A personal experience. Procedia-Social and Behavioral Sciences, 42, 451-459.

Jenkins, O. H. (1999). Understanding and measuring tourist destination images. International Journal of Tourism Research, 1(1), 1-15.

Joppe, M., Martin, D. W., \& Waalen, J. (2001). Toronto's image as a destination: a comparative importance-satisfaction analysis by origin of visitor. Journal of Travel Research,39(3), 252-260.

Juaneda, C. (1996). Estimating the probability of return visits using a survey of tourist expenditure in the Balearic Islands. Tourism Economics, 2(4), 339-352.

Kline, R. B. (2011). Principles and practice of structural equation modeling. New York: Guilford Press.

Kotler, P., Bowen, J., \& Makens, J. (1996). Marketing for hospitality and tourism. New Jersey: Prentice-Hall.

Kozak, M. (2001). Repeaters' behavior at two distinct destinations. Annals of Tourism Research, 28(3), 784-807.

Kozak, M., \& Rimmington, M. (2000). Tourist satisfaction with Mallorca, Spain, as an off-season holiday destination. Journal of Travel Research, 38(3), 260-269. 
INTERNATIONAL JOURNAL OF ACADEMIC RESEARCH IN ACCOUNTING, FINANCE AND

MANAGEMENT SCIENCES

Vol. 10, No. 3, 2020, E-ISSN: 2225-8329 @ 2020 HRMARS

LaBarbera, P. A., \& Mazursky, D. (1983). A longitudinal assessment of consumer satisfaction/dissatisfaction: The dynamic aspect of the cognitive process. Journal of Marketing Research, 20(November), 393-404.

Lee, T. H. (2013). Influence analysis of community resident support for sustainable tourism development. Tourism Management, 34, 37-46.

Lee, C.-K., Lee, Y.-K., \& Lee, B. (2005). Korea's destination image formed by the 2002 World Cup. Annals of Tourism Research, 32(4), 839-858.

Leisen, B. (2001). Image segmentation: the case of a tourism destination. Journal of Services Marketing, 15(1), 49-66.

Lo, M. C., Mohamad, A. A., Songan, P., \& Yeo, A. W. (2012). Positioning rural tourism: Perspectives from the local communities. International Journal of Trade, Economics and Finance, 3(1), 59.

Lounsbury, J. W., \& Hoopes, L. L. (1985). An investigation of factors associated with vacation satisfaction. Journal of Leisure Research, 17(1), 1-13.

Mayer, K. J., Johnson, L., Hu, C., \& Chen, S. (1998). Gaming customer satisfaction: An exploratory study. Journal of Travel Research, 37(2), 178-183.

Milman, A., \& Pizam, A. (1995). The role of awareness and familiarity with a destination: The central Florida case. Journal of Travel Research, 33(3), 21-27.

McCool, S. F., Moisey, R. N., \& Nickerson, N. P. (2001). What should tourism sustain? The disconnect with industry perceptions of useful indicators. Journal of Travel Research, 40(2), 124-131.

McDougall, G. H., \& Levesque, T. (2000). Customer satisfaction with services: putting perceived value into the equation. Journal of Services Marketing, 14(5), 392-410.

Murphy, P., Pritchard, M. P., \& Smith, B. (2000). The destination product and its impact on traveller perceptions. Tourism Management, 21(1), 43-52.

Nunally, J. C., \& Bernstein, I. H. (1994). Psychometric theory (3rd ed.). New York: McGraw- Hill.

Nunkoo, R., \& Ramkissoon, H. (2011). Developing a community support model for tourism. Annals of Tourism Research, 38(3), 964-988.

Nzama, A. T. (2008). Socio-cultural impacts of tourism on the rural areas within the World Heritage Sites-The case of KwaZulu-Natal, South Africa. South Asian Journal of Tourism and Heritage, 1(1), 1-8.

Oppermann, M. (2000). Tourism destination loyalty. Journal of Travel Research, 39(1), 78-84.

Oppermann, M. (1996). Convention destination images: analysis of association meeting planners' perceptions. Tourism Management, 17(3), 175-182.

Oye, N. D., Okafor, C. I., \& Kinjir, S. (2013). Sustaining tourism destination competitiveness usingICT in developing countries. International Journal of Computer and Information Technology, 2(1), 48-56.

Bajs, P. I. (2015). Tourist perceived value, relationship to satisfaction, and behavioral intentions: The example of the Croatian tourist destination Dubrovnik. Journal of Travel Research, 54(1), 122-134

Phelps, A. (1986). Holiday destination image-the problem of assessment: An example developed in Menorca. Tourism Management, 7(3), 168-180.

Philips, L. W., Bagozzi, R. P., \& Yi, Y. (1991). Assessing construct validity in organizational research. Administrative Science Quarterly, 36, 421-citation_lastpage. 
INTERNATIONAL JOURNAL OF ACADEMIC RESEARCH IN ACCOUNTING, FINANCE AND

MANAGEMENT SCIENCES

Vol. 10, No. 3, 2020, E-ISSN: 2225-8329 @ 2020 HRMARS

Pizam, A., \& Ellis, T. (1999). Customer satisfaction and its measurement in hospitality enterprises. International Journal of Contemporary Hospitality Management, 11(7), 326-339.

Pritchard, M., \& Howard, D. R. (1997). The loyal traveler: Examining a typology of servicepatronage. Journal of Travel Research, 35(4), 2-10.

Poon, A. (1993). Tourism, technology and competitive strategies. CAB international.

Reisinger, Y., Turner, L. (2003). Cross-cultural Behaviour in Tourism: Concepts and Analysis. Butterworth Heinemann: Oxford, UK.

Ross, G. F. (1993). Destination evaluation and vacation preferences. Annals of Tourism Research, 20, 477-489.

Ross, L. D., \& Iso-Ahola, S. E. (1991). Sightseeing tourists' motivation and satisfaction. Annals of Tourism Research, 18(2), 226-237.

Ruiz-Ballesteros, E. (2011). Social-ecological resilience and community-based tourism: an approach from Agua Blanca, Ecuador. Tourism Management, 32(3), 655-666.

Rust, R. T., \& Oliver, R. L. (1994). Service quality: insights and managerial implications from the frontier. Service quality: New Directions in Theory and Practice, 1-19.

Rust, R. T., \& Zahorik, A. J. (1993). Customer loyalty, customer retention and market share. Journal of Retailing, 69(2), 193-215.

Seaton, A. V., \& Benett, M. M. (1996). Marketing tourism products: Concepts, issues, cases. London: International Thomson Business Press.

Schubert, S. F., Brida, J. G., \& Risso, W. A. (2011). The impacts of international tourism demand on economic growth of small economies dependent on tourism. Tourism Management, 32(2), 377-385.

Taylor, S. A., \& Baker, T. L. (1994). An assessment of the relationship between service quality and customer satisfaction in formation of consumers' purchase intentions. Journal of Retailing, 70(2), 163-178.

Telisman-Kosuta, N. (1994). Tourist destination image. En WITT, S. \& Moutinho, L. (Eds): Tourism Marketing and Management Handbook (pp. 557-561).

Thongma, W., Leelapattana, W., \& Hung, J. T. (2012). Tourists' satisfaction towards tourism activities management of Maesa community, Pongyang Sub-District, Maerim District, Chiang Mai Province, Thailand. Retrieved from http://iscthlr.turismo.wuwien.ac.at/files/papers/p47_fullpaper.pdf

Twining-Ward, L., \& Butler, R. (2002). Implementing STD on a small island: Development and use of sustainable tourism development indicators in Samoa. Journal of Sustainable Tourism, 10(5), 363-387.

Woodruff, R. B. (1997). Customer value: the next source for competitive advantage. Journal of The Academy of Marketing Science, 25(2), 139.

Woodside, A. G., \& Lysonski, S. (1989). A general model of traveller destination choice. Journal of Travel Research, 27(4), 8-14.

Yau, O. H. M., \& Chan, C. F. (1990). Hong Kong as a travel destination in Southeast Asia: A multidimensional approach. Tourism Management, 11(2), 123-132.

Yoon, Y., \& Uysal, M. (2005). An examination of the effects of motivation and satisfaction on destination loyalty: a structural model. Tourism Management, 26(1), 45-56.

Yozcu, O. K. (2017). Competitiveness of Istanbul as a tourism destination for luxury market. Journal of Tourismology, 3(2), 2-13. 
INTERNATIONAL JOURNAL OF ACADEMIC RESEARCH IN ACCOUNTING, FINANCE AND MANAGEMENT SCIENCES

Vol. 10, No. 3, 2020, E-ISSN: 2225-8329 @ 2020 HRMARS

Zhang, H., \& Lei, S. L. (2012), 'A structural model of residents' intention to participate in ecotourism: The case of a wetland community', Tourism Management, vol. 33, pp. 916-925.

Zehrer, A., Smeral, E., \& Hallmann, K. (2017). Destination competitiveness - A comparison of subjective and objective indicators for winter sports areas. Journal of Travel Research, 56(1), 55-56.

Zeithaml, V. A. (1988). Consumer perceptions of price, quality, and value: a means-end model and synthesis of evidence. Journal of Marketing, 52(3), 2-22. 